\title{
SPOT MURAL SEBAGAI ATRAKSI WISATA DI DESA TOYOMARTO KECAMATAN SINGOSARI KABUPATEN MALANG \\ Oleh:
}

Dr. Eti Setiawati, M.Pd ${ }^{1}$., Millatuz Zakiyah, S.Pd., M.A. ${ }^{2}$., Nanang Bustanul Fauzi, S.S., M.Pd. ${ }^{3}$, I KadekYudiAstawan, M.Sn. ${ }^{4}$

1 Pendidikan Bahasa dan Sastra Indonesia, Universitas Brawijaya

3banyubening@ub.ac.id

\begin{abstract}
Abstrak
Pengabdian masyarakat ini berfokus pada pembangunan citra desa Toyomarto sebagai desa air. Pengabdian ini dilatarbelakangi oleh letak Desa Toyomarto yang memiliki situs bersejarah dan menjadi tujuan wisata, yaitu Situs Sumberawan. Berdasarkan data awal tersebut, potensi sejarah dan budaya yang ada di Desa Toyomarto harus dikembangkan dan dikenalkan pada masyarakat.

Tim Pengabdian masyarakat berkontribusi untuk meningkatkan citra Desa Toyomarto melalui spot mural berbasis sejarah dan budaya. Mural tersebut diharapkan dapat menambah daya tarik wisatawan untuk mengunjungi Situs Sumberawan atau Tirta Amerta Sari. Hasil pengabdian masyarakat ini memberi dampak positif pada masyarakat Desa Toyomarto. Hal itu tampak pada peningkatan kesejahteraan ekonomi masyarakat baik secara langsung maupun tidak langsung. Selain itu, media spot mural juga menjadi media pembelajaran sejarah dan budaya bagi masyarakat atau wisatawan yang berkunjung ke Desa Toyomarto.
\end{abstract}

Kata Kunci: mural, atraksi wisata, Toyomarto

\section{Abstract}

Keywords: murals, tourist attractions, Toyomarto

\section{PENDAHULUAN}

Desa Toyomarto merupakan salah satu desa di wilayah Kecamatan Singosari Kabupaten Malang dengan luas wilayah kurang lebih 905 hektar. Desa Toyomarto memiliki visi dan misi, visi dari Desa Toyomarto yaitu "terbangunnya tata kelola pemerintahan desa yang baik dan bersih guna mewujudkan kehidupan masyarakat desa yang adil, makmur, dan sejahtera 'mewujudkan kebersamaan, keharmonisan menuju masyarakat madani' " (Laporan Penyelenggaraan Pemerintahan Desa, 2018: 8). Misi dari Desa Toyomarto, yaitu: (1) mendorong masyarakat dalam penuntasan wajib belajar pendidikan dasar 9 tahun dan turut mengoptimalkan peran PKBM (Pusat Kegiatan Belajar Masyarakat) dalam pengembangan pendidikan luar sekolah melalui kejar paket; (2) mendorong peningkatan kesehatan lingkungan dan pola hidup sehat; (3) mendorong penguatan dan pengembangan peran koperasi; (4) mendorong penguatan pembinaan dalam pemberdayaan peran perempuan dan generasi muda serta potensi masyarakat lainnya; (5) mendorong penguatan perekonomian masyarakat dari potensi desa khususnya pengembangan periwisata dan home industry ; (6) mendorong penguatan peningkatan kualitas kehidupan sosial yang harmonis berlandaskan semangat gotong royong dan nilai-nilai akhlaqul karimah (Laporan Penyelenggaraan Pemerintahan Desa, 2018:8-9).

Desa Toyomarto merupakan desa yang unik karena kaya akan budaya. Dalam perspektif pariwisata, desa ini memiiki cukup banyak potensi yang layak jual. Dalam misi desa, tertuang tujuan untuk mewujudkan penguatan sekaligus pengembangan desa yang bersumber dari sektor UMKM dan pariwisata. Hal ini tentunya sangat beralasan karena desa ini memiliki banyak potensi 
pariwisata, khususnya dalam bidang budaya dan UMKM.

Dalam mewujudkan cita-cita tersebut, desa tentu membutuhkan desain utama yang mampu mencitrakan Toyomarto sebagai desa wisata. Dalam hal ini, desa membutuhkan beberapa hal yang menjadi sarana pendukung pengembangan potensi wisata tersebut. Sarana pendukung ini bisa berupa sarana fisik maupun non fisik. Sarana non fisik yang paling dibutuhkan dalam upaya pengembangan potensi wisata tersebut promosi wisata yang ruang lingkupnya luas.

Dalam upaya mencari identitas yang mampu menjadi citra desa, tim Jurusan Bahasa FIB UB sepakat untuk menjadikan air sebagai tema utama. Air dipilih karena menjadi asal muasal desa dan mempunyai hubungan erat dengan sejarah dan pola kehidupan setempat. Tim pengabdian memilih mural sebagai langkah awal membangun desain utama yang mampu membangun citra desa. Terkait dengan hal itu, maka disusunlah langkah sebagai berikut: (1) Prakegiatan, yaitu berupa wawancara dengan perangkat desa mengenai potensi wilayah dan strategi pemasarannya, (2) Proses kegiatan, yaitu penggalian data berupa foto, data pendukung berita, dan pelaksanaan. Didasarkan hal ini, dapat dirumuskan masalah, yaitu (a) bagaimana air sebagai cikal bakal citra desa dijadikan ide utama gambar mural dan (2) bagaimana pelaksanaan gambar dinding di Desa Toyomarto?

\section{METODE}

Berdasarkan data awal, terdapat kelemahan dalam masyarakat Desa Toyomarto dalam hal desain utama yang hendak dijadikan dasar pencitraan. Oleh karena itu, kegiatan ini dilaksanakan untuk membuat mural dalam upaya paling awal mewujudkan citra desa. Dalam kaitannya dengan ini, mural akan melibatkan ahli desain yang menerjemahkan konsep dalam bentuk visual.

Realisasi pemecahan masalah dilakukan dalam tiga tahap, pertama penyusunan konsep mural sebagai atraksi wisata, kedua, tahap pelaksanaan dengan melakukan pemuralan, dan ketiga tahap evaluasi dan pelaporan. Konsep mural berupa gambar yang diinspirasi cerita rakyat di Desa Toyomarto. Kegiatan pemuralan dilakukan pada bulan Oktober 2020 di Pemandian Pentungan Sari Desa Toyomarto Kecamatan Singosari. Penyerahan simbolis dilakukan pada 27 Oktober 2020. Tahap evaluasi dilakukan dengan cara rapat bersama pihak
Desa Toyomarto Kecamatan Singosari pada tanggal 1 November 2020.

Menguraikan cara yang digunakan untuk menyelesaikan masalah, tantangan, atau persoalan. Dalam hal ini, dapat digunakan satu jenis metode ataupun kombinasi beberapa jenis metode. Beberapa contoh metode sebagai berikut.

Kegiatan ini secara umum ditujukan bagi kepentingan Desa Toyomarto. Namun, secara khusus ditujukan kepada masyarakat setempat dan pengunjung desa. Hal ini bertujuan untuk menampilkan citra desa dalam bentuk visual yang mudah diingat.

Metode kegiatan ini dilakukan sebagai berikut.

1. Observasi dan wawancara yang berguna untuk mengetahui problematika yang dihadapi perangkat Desa Toyomarto.

2. Sosialisasi yang bertujuan untuk mempublikasikan kegiatan pengabdian kepada perangkat desa.

3. Pembuatan gambar mural bertema budaya dan sejarah Desa Toyomarto Singosari Malang.

4. Evaluasi akhir yang bertujuan untuk mengetahui gambar mural bertema sebagai wujud pengenalan kegiatan cinta tanah air dan kegiatan pengenalan budaya permainan tradisional.

\section{HASIL DAN PEMBAHASAN}

Berdasarkan hasil observasi dan wawancara pada narasumber didapatkan data bahwa nama Desa Toyomarto berasal dari sumber mata air yang ada di desa tersebut. Kata 'Toyo' berarti air, sedangkan kata 'amerto' bermakna hidup. Secara bahasa dapat disimpulkan bahwa kata 'Toyomarto' merupakan representasi dari air yang selalu hidup di wilayah itu. Oleh karena itu, dapat disimpulkan bahwa Desa Toyomarto merupakan desa yang memiliki sumber mata air yang selalu hidup dan mata air itu menjadi tumpuan dalam memenuhi kebutuhan hidup masyarakat desa sehari-hari.

Dalam menjaga kelestarian sumber mata air itu, masyarakat Desa Toyomarto mengadakan selametan satu kali dalam setahun. Selametan itu dilaksanakan pada bulan Suro berdasarkan penanggalan Jawa (bulan Muharram pada penanggalan Hijriah).

Kemudian, pada selametan mata air tahun 2016 muncul istilah 'Tirta Amerta Sari' yang mewakili nama Toyomarto. Kata 'Tirta' bermakna air, 'amerta' bermakna hidup, dan 'sari' bermakna inti. Istilah Tirta Amerta Sari dapat diartikan bahwa air merupakan sumber 
penghidupan yang dibutuhkan masyarakat dalam memenuhi kebutuhan hidupnya seharihari.

Berdasarkan sejarah dan latar belakang terbentuknya Desa Toyomarto itu, tim pengabdian dan perangkat desa bekerja sama untuk mengangkat citra Desa Toyomarto sebagai Desa Air. Hal tersebut didasari oleh identitas lokal yang dimiliki Desa Toyomarto sebagai desa dengan sumber mata air yang tidak pernah mati. Perangkat desa mengharapkan identitas lokal Desa Toyomarto sebagai Desa Air menjadi grand design dari desa tersebut.

Oleh sebab itu, tim pengabdian menginisiasi spot mural yang berbasis sejarah dan budaya tentang asal mula Desa Toyomarto. Spot mural tersebut dimaksudkan sebagai daya tarik wisatawan sekaligus sebagai representasi visual tentang sejarah asal mula Desa Toyomarto atau Tirta Amerta Sari.

Sebelum eksekusi mural yang telah didesain, terlebih dahulu tum mensosialisasikannya kepada pihak desa. Aca tersebut bertujuan untuk diseminasi hasil desain kepada perangkat desa agar mereka memahami konsep mural yang hendak dibuat. Dalam pertemuan tersebut, terdapat masukan-masukan yang kemudian diterjemahkan dalam bentuk gambar yang turut memperkaya desain mural. Setelah dicapai kesepakatan, tim kemudian mengeksekusi mural pada tembok di wilayah wisata Pentungan Sari. Berikut dokumentasi dari proses pembuatan mural di Desa Toyomarto.

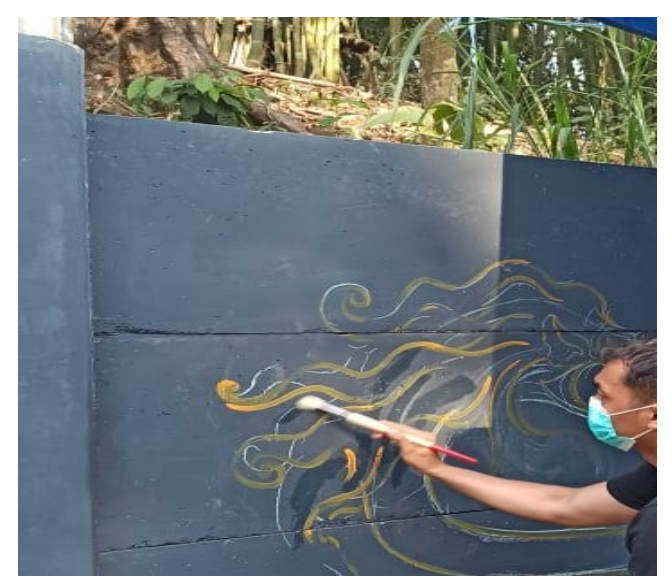

Gambar 1. Proses Pembuatan Mural

Setelah proses pembuatan mural itu selesai, beberapa hasil mural mampu menggambarkan kisah tentang asal mula munculnya Tirta Amerta Sari atau sumber mata air yang tidak pernah mati di Desa Toyomarto. Berikut beberapa gambar mural yang ada di Desa Toyomarto.

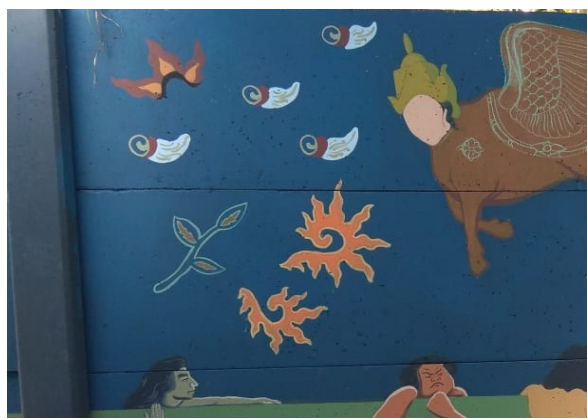

Gambar 2. Mural Pencarian Tirta

Mural gambar 2 menceritakan tentang pencarian air suci (tirta amerta). Gambar tersebut mewakili cerita saat Sang Hyang Nārāyana (Wisnu) mengatakan bahwa tirta tersebut berada di dasar laut Ksira. Cara mendapatkannya adalah dengan mengaduk lautan tersebut. Para Dewa, Detya, dan Raksasa menuju Laut Ksira. Kemudian, Naga Basuki mencabut gunung Mandara (Mandaragiri) di Pulau Sangka sebagai tongkat pengaduk. Gunung tersebut dibawa ke tengah lautan. Seekor kura-kura (Akupa/Kurma) besar menjadi penyangga/dasar gunung tersebut (lihat gambar 3.). Sang Naga melilit gunung tersebut, kemudian para Dewa memegang ekornya, sedangkan Raksasa dan Detya memegang kepalanya. Dewa Indra berdiri di puncaknya agar gunung tidak melambung ke atas. Beberapa lama setelah gunung diputar, keluarlah Ardhachandra, Dewi Sri, Dewi Lakshmi, kuda Uccaihsrawa, dan Kastubhamani. Semuanya berada di pihak para Dewa. kemudian, munculah Dhanwantari membawa kendi tempat tirta amerta.

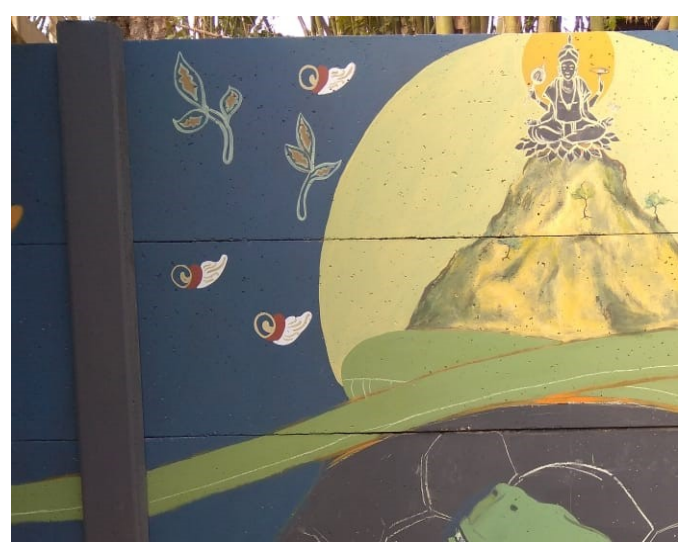


Gambar 3 Akupa yang menggendong Mandra

Kemudian, tim pengabdian masyarakat melaksanakan penyerahan mural secara simbolis kepada masyarakat Desa Toyomarto, Kecamatan Singosari pada tanggal 27 Oktober 2020. Penyerahan simbolis dilakukan dengan cara menggoreskan kuas pada mural tersebut. Hal ini menandai penyerahan mural tersebut kepada pihak desa agar dapat menjaga dan melestarikan Tirta Amerta Sari sekaligus Spot Mural yang menjadi wadah dari cerita rakyat asal mula Desa Toyomarto.

Spot Mural sebagai atraksi wisata diharapkan mampu meningkatkan perekonomian warga desa, baik secara langsung maupun tidak langsung. Keberadaan spot mural di Desa Toyomarto menambah daya tarik wisatawan untuk berkunjung dan menambah wawasan bagi masyarakat desa tentang asal mula Desa Toyomarto.

Setelah penyerahan simbolis dilakukan, kemudian dilakukan evaluasi terhadap pemuralan dengan pihak desa pada tanggal 01 November 2020. Hal ini dilakukan untuk mengetahui respon masyarakat terhadap kegiatan ini. Berdasarkan hasil diskusi dengan pihak desa, diketahui bahwa mural yang dibuat oleh tim pengabdian disambut antusias oleh masyarakat. Masyarakat menjadi lebih tertarik untuk datang ke pemandian. Hal ini juga diiringi dengan menambahnya pendapatan desa sekaligus majunya perekonomian masyarakat setempat. Selain itu, masyarakat juga lebih paham terhadap cerita rakyat tentang asal mula Desa Toyomarto yang selama ini diwariskan secara turun temurun.

\section{SIMPULAN DAN SARAN}

\section{Simpulan}

Berdasarkan hasil dan pembahasan, dapat disimpulkan bahwa kegiatan pengabdian berupa Pembuatan Spot Mural sebagai Atraksi Wisata di Desa Toyomarto Kecamatan Singosari Kabupaten Malang memberikan dampak positif bagi masyarakat desa Toyomarto. Dampak positif ini berupa peningkatan kesejahteraan ekonomi masyarakat secara tidak langsung tanpa meninggalkan esensi pembelajaran sejarah dan budaya. Mural ini dapat menjadi spot foto yang menambah daya tarik wisatawan untuk mengunjungi situs Sumberawan sekaligus memberikan pelajaran sejarah dan budaya bagi masyarakat dan para pengunjung.

\section{Saran}

Masyarakat Desa Toyomarto diharapkan dapat menjaga, dan memanfaatkan adanya mural ini sebagai spot foto dengan mempromosikannya di akun instagram dan/atau media daring lain yang sesuai kebutuhan. Selain itu, diharapkan terdapat kegiatan pengabdian lanjutan untuk mengembangkan beragam potensi lain yang dimiliki oleh Desa Toyomarto, sehingga dapat membantu meningkatkan kesejateraan ekonomi masyarakat.Pada bagian ini, terdapat dua subbagian, yaitu simpulan dan saran

\section{DAFTAR PUSTAKA}

Asharhani, Imaniar Sofia. (2012). "Mural dan Graffiti sebagai Elemen Pembentuk Townscape". Depok: Universitas Indonesia.

Depdiknas. 2003. Undang-Undang Nomor 20 Tahun 2003 tentang Sistem Pendidikan Nasional. Jakarta: Dikdasmen

Ibrahim. 2015. Metodologi Penelitian Kualitatif . Bandung: Afabeta Laporan Penyelenggaraan Pemerintah Desa (LPPD). $2018 . \quad$ Laporan Penyelenggaraan Pemerintah

Desa (LPPD) Desa Toyomarto Akhir Tahun Anggaran 2018. http://desatoyomarto.malangkab.go.id/diakses pada 25 Maret 2020.

Putrialam, S. (2014). "ANALISIS SEMIOTIKA:KONSTRUKSI PERLAWANAN PADA MURAL "WHAT'S NEXT INDONESIA BATIK" (Doctoral dissertation, UNIVERSITAS AIRLANGGA). Commonline Departemen Komunikasi| Vol. 3/ No. 2

Saring, Marsudi. 2006. Permasalahan Dan Bimbingan Di Taman Kanak-kanak . Surakarta: UMS. Tidak Diterbitkan.

Tadkiroatun, Musfiroh. 2005. Bercerita Untuk Anak Usia Dini . Jakarta: Departemen Pendidikan Nasional.

Wicandra, O. B. (2009). Berkomunikasi Secara Visual Melalui Mural di Yogyakarta. Nirmana, 7(2). http://desamulyoagung.blogspot.com diakses 28 Agustus 2018. 